\title{
Landforms contribute to plant biodiversity at alpha, beta and gamma levels
}

Running title: Landforms increase plant biodiversity

Helena Tukiainen”; Mikko Kiuttu; Risto Kalliola; Janne Alahuhta; Jan Hjort ${ }^{1}$

\author{
${ }^{1}$ Geography Research Unit, University of Oulu, P.O. Box 8000, Oulu, FI 90014, Finland \\ ${ }^{2}$ Rokua Geopark, Jaakonjärventie 2, 91670 Rokua, Finland \\ ${ }^{3}$ Geography section, Department of Geography and Geology, FI-20014 University of Turku, Finland \\ *helena.tukiainen@oulu.fi
}

\section{Acknowledgements}

We would like to thank the handling editor, Carina Hoorn, for constructive suggestions that have substantially improved the manuscript. In addition, we would like to thank Tuija Maliniemi and Tanja Huhtahaara for their contribution in vascular plant data inventories. Helena Tukiainen was supported by Kone Foundation and Jan Hjort by the Academy of Finland (Projects 285040 and 315519).

\section{Abstract}

Aim: Geodiversity underpins biodiversity, but the contribution of specific geofeatures or landforms has rarely been explored. In this study we use multiple vascular plant species diversity measures on alpha, beta and gamma levels to explore the linkage between biodiversity and co-located landforms (e.g. gullies, dunes and lake shores). We hypothesize that biodiversity will be positively related to geodiversity, which is founded on distinct landforms. Additionally, we propose that different landforms will sustain different amounts of biodiversity and that high alpha and gamma diversity values are related to landform-driven moisture availability whereas high beta diversity relates especially to landform-specific microtopographic variation.

Location: Rokua UNESCO Global Geopark area, Finland.

Taxon: Vascular plants.

Methods: We compare vascular plant species richness measures, Shannon's and Simpson's diversity indices, rarity-weighted richness and local contribution to beta diversity at altogether three levels of biodiversity (alpha, beta and gamma) for different landforms. Landform information is compiled from aerial photos, spatial data layers and targeted field surveys. We compare results to control habitat (i.e. sites without any distinct landforms) within the study area.

Results: Vascular plant diversity was higher on landforms than in control habitat. There was also notable variation between species diversity of different landforms. Moisture-rich gullies and river shores were especially diverse at all three levels, whereas aapa mires hosted most unique species composition (highest beta diversity). Beta diversity patterns were rather comparable with alpha and gamma diversity patterns, which contradicts our hypothesis. 
Main conclusions: This study quantitatively established a strong connection between terrestrial plant communities and multiple landforms. Our results highlighted the landform-controlled variation in soil moisture, microclimate and microtopography in enhancing plant species diversity. Based on the results, we promote the inclusion of landform-based geodiversity information in conservation management and in further biogeographical studies.

Keywords: biodiversity, Conserving Nature's Stage, geodiversity, geofeature, geomorphology, Geopark, microhabitats, rarity-weighted richness, vascular plants

\section{Introduction}

Biodiversity loss is one of the greatest challenges related to global change (Secretariat of the Convention on Biologival Diversity, 2014). Multiple conservation actions have been conducted both locally and globally, but despite some localized successes, the rate of biodiversity loss is not slowing (Butchart et al., 2010; WWF, 2018). Increasing our knowledge of the abiotic factors affecting biodiversity at local, betweencommunity and regional levels is essential when future challenges in environmental conservation are considered (Whittaker, Willis, \& Field, 2001). This is especially important at high latitudes, which will likely face the strongest changes due to climate warming (ACIA, 2005; Post et al., 2009; Vilmi et al., 2017; IPCC, 2018).

The importance of geodiversity and geological heritage - in addition to biodiversity - is now increasingly accepted among scientists and conservation practitioners and should be considered in nature conservation planning and management (Burek \& Prosser, 2008; Hjort, Heikkinen, \& Luoto, 2012; Matthews, 2014). Geodiversity is commonly defined as the variety of earth surface materials, landforms and processes (geological, geomorphological and hydrological); or more generally the abiotic diversity of the earth's surface (Gray, 2013). Geodiversity is comprised of geofeatures (i.e. geodiversity elements like individual landforms, hydrological features or geological types) that constitute the abiotic landscape (Hjort \& Luoto, 2010; Hjort, Gordon, Gray, \& Hunter, 2015; Brilha, 2016; Bailey, Boyd, Hjort, Lavers, \& Field, 2017). For nature conservation purposes, it is essential to understand which geofeatures play a significantly large role in maintaining both geo- and biodiversity (Sharples, 1995; Erikstad, 2013). Moreover, geofeatures (e.g. landforms, like gullies and lake shores) are globally common and occur across biomes.

Geodiversity has been proposed as a useful approach to explore and understand biodiversity patterns (Jedicke, 2001; Jačková \& Romportl, 2008; Parks \& Mulligan, 2010; Najwer et al., 2016). In recent years, Conserving Nature's Stage (CNS) has been advanced as an important conservation principle stating that geodiversity could be used as a coarse filter strategy for conserving biodiversity (Beier et al., 2015). Instead of targeting individual species or habitats for conservation, the CNS principle targets areas that are capable of supporting high biodiversity under future environmental changes (Bailey et al., 2017). Landforms support biodiversity by creating micro-climatic variability and niche-space and by controlling hydrology (Nichols, Killingbeckm, \& August, 1998; Dobrowski, 2011; Matthews, 2014; Lawler et al., 2015). Landforms, such as landslide scars (Alexandrowicz \& Margielewski, 2010), and earth surface processes (le Roux \& Luoto, 2014) can be important determinants of plant distributions. Thus, maintaining a varied physical landscape will enable diverse ecological processes, both protecting and promoting biological diversity (Lawler et al., 2015; Antonelli et al., 2018).

Ecologists have devoted considerable effort to the explanation of patterns of biological diversity at different levels (i.e. alpha, beta and gamma) and across environmental gradients in ecological systems (Humboldt, 1807; Peet, 1974; Magurran, 2004). The novel idea of studying the distribution of plant and animal species in relation to varying physical conditions was already proposed by Alexander von Humboldt over two hundred years ago (Humboldt, 1807). Still, the relationships between explicit geodiversity and 
biodiversity measures have been examined rarely. Recent studies have explored the links between geodiversity and biodiversity in landscape-scale (Jačková \& Romportl, 2008; Hjort et al., 2012; Kougioumoutzis \& Tiniakou, 2014; Najwer, Borysiak, Gudowicz, Mazurek, \& Zwoliński, 2016; Tukiainen et al., 2017; Bailey, Boyd, \& Field, 2018). These studies have shown that geodiversity may help explain spatial biodiversity patterns at mesoscale levels. Bailey et al. (2017) found that while automatically extracted landform data added the most explanatory power to species richness models (smallest study unit 1-km²), hydrological and material-based (soil, geology, superficial deposits) geofeatures were also significant. Their results emphasize the importance of analyzing distinct landforms in biodiversity modelling.

The diversity of abiotic nature underpins biodiversity (Lundholm, 2009; Beier et al., 2015), but there is a lack of studies where their relationship is examined at local scale (e.g. from a landform perspective) and with multiple aspects of biodiversity. In this study, we focus on the multi-level biodiversity (alpha, beta and gamma) of individual landforms that is calculated with a number of measures (e.g. species richness and diversity indices). Landforms sustain various microtopographical and microclimatic conditions, which affect positively on species diversity by producing various niche space (Carson et al., 2009; Lenoir, Hattab, \& Pierre, 2017; Lembrechts, Nijs, \& Lenoir, 2018). By comparing the plant diversity across landforms and across the different diversity levels we will gain essential knowledge which helps to estimate the feasibility of the CNS strategy on management scale, beyond current studies. Landforms are usually easy to map from Light Detection and Ranging (LiDAR) based digital elevation models (DEMs) and remote sensing data which makes them a cost-efficient option to examine environment-biodiversity relationships across biomes.

In this study, vascular plant species richness data were collected in field inventories from 1535 1- $\mathrm{m}^{2}$ quadrats in Rokua UNESCO (United Nations Educational, Scientific and Cultural Organisation) Global Geopark area, Finland. Co-located landform data were compiled from aerial photos, spatial data layers and targeted field surveys. We built a catalog of biodiversity and different landforms (kettle holes, kamehummocks, near-shore sand dunes, parabolic sand dunes, deflation basins, beach ridges, lake and river shores, gullies and aapa mires; see Fig. $1 \& 2$ ). With this data we are seeking answers to three main study questions: (1) are there differences in biodiversity between distinct landforms and control sites (i.e., null model, areas where no distinct landforms were observed), (2) how does biodiversity vary among different landforms, and (3) how do the results vary between different diversity levels (alpha, beta and gamma).

Firstly, we hypothesize that biodiversity is higher on distinct landforms compared to control sites $\left(\mathrm{H}_{1}\right)$ because landforms vary significantly e.g. in their local resource availability, habitat diversity and niche variety (Bétard, 2013; Stein, Gerstner, \& Kreft, 2014; Albano, 2015). Secondly, we hypothesize that different landforms sustain different amounts of biodiversity regardless of the used diversity measure $\left(\mathrm{H}_{2}\right)$. We expect that gullies, river shores and lake shores will be the most diverse landforms, whereas near-shore dunes and beach ridges are expected to have the lowest biological diversity. This is because the availability of soil moisture and the proximity of ground water to the soil surface embraces high diversity and riparian zones are often hotspots of plant species richness (Kalliola \& Puhakka, 1988; Malanson, 1993; Eurola \& Huttunen, 2006; Jansson, Laudon, Johansson, \& Augspurger, 2007). For contrast, in dry and sandy environments the diversity is generally low (Chipman \& Johnson,2002; Tilk, Mandre, Jaan, \& Kõresaar, 2011; Ujházy, Fanta, \& Prach, 2011). We also hypothesize that alpha and gamma diversity have similar patterns among different landforms whereas beta diversity varies in a more unique way $\left(\mathrm{H}_{3}\right)$. We presume landform controlled soil moisture and its variability to be the main driver of local and regional level biodiversity patterns, whereas landforms with pronounced microtopographical variation, such as aapa mires and gullies, are assumed to have high beta diversity (Meynard et al., 2011). 

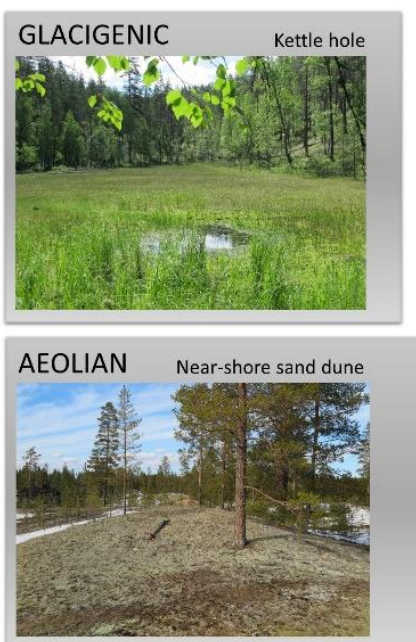

LITTORAL Beach ridge
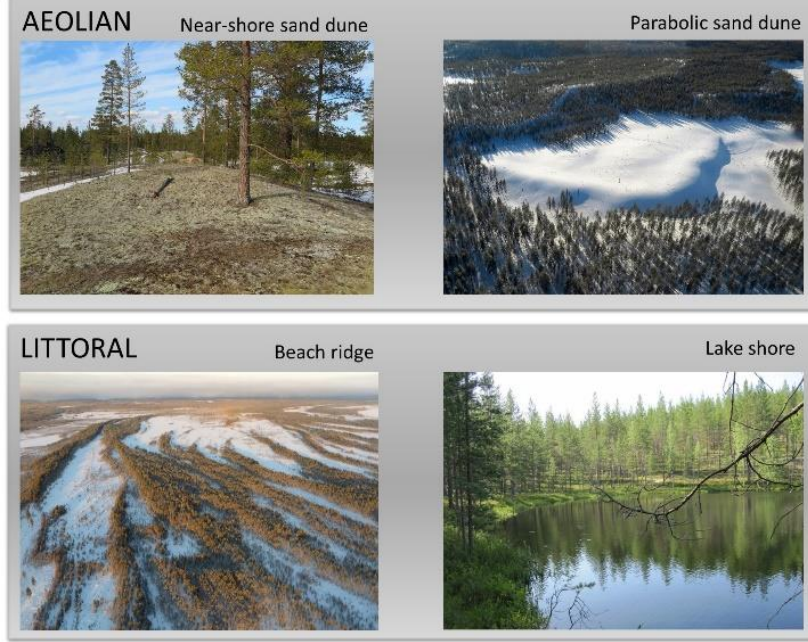

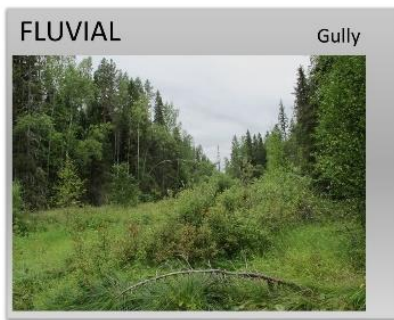

Deflation basin
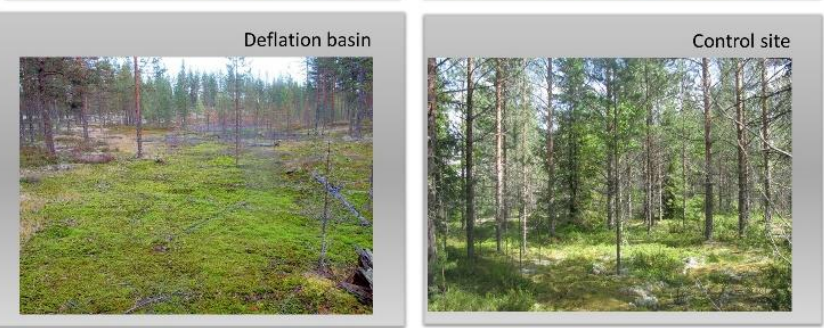

Figure 1. Photograph of each landform and control site (no distinguishable landform at the studied scale) at the study area in Rokua UNESCO Global Geopark, Finland. Note that the figures of parabolic dune and beach ridge are taken in winter and there is snow on the ground. Photos: Mikko Kiuttu and Helena Tukiainen. 


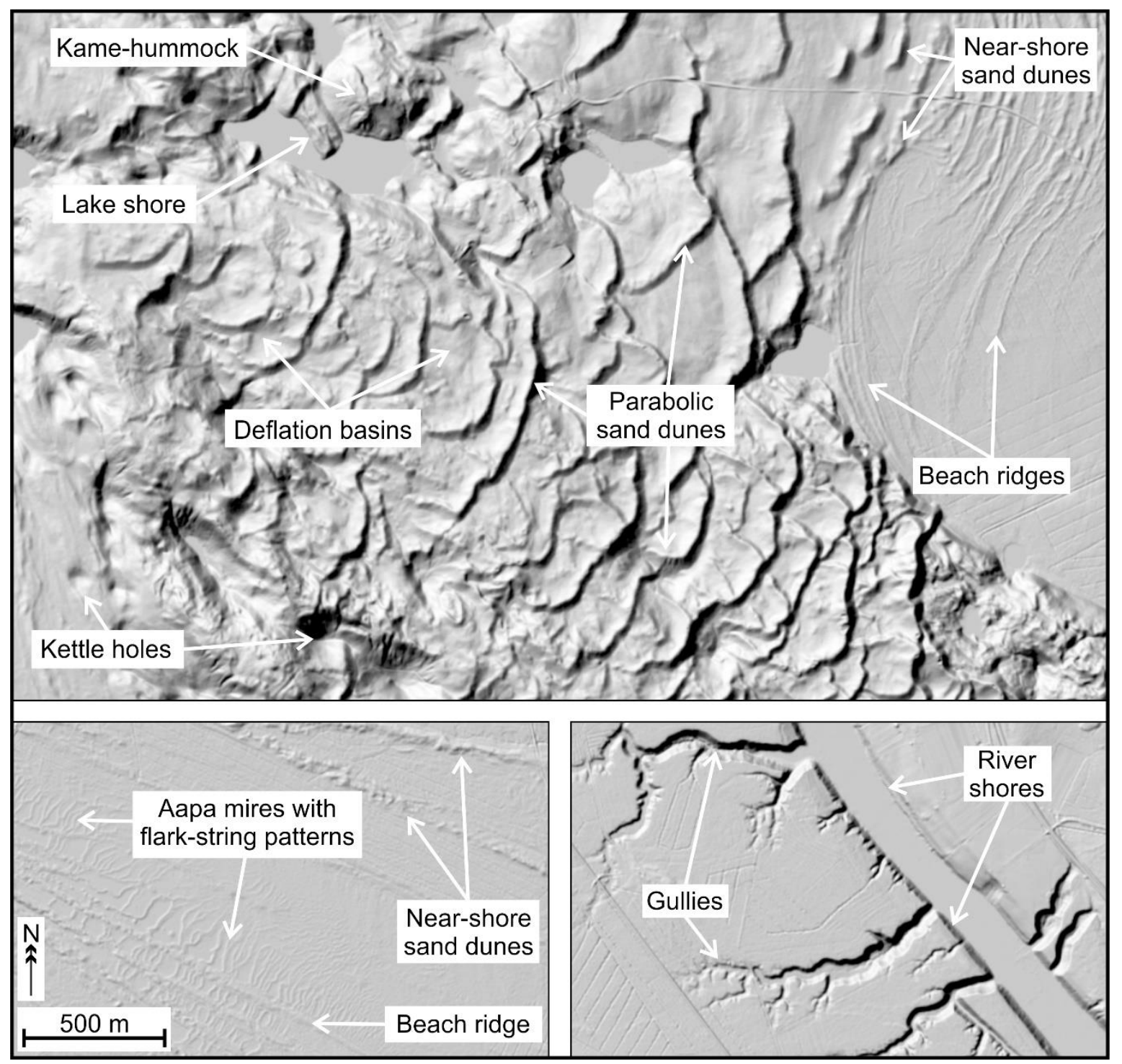

Figure 2. High-resolution terrain views showing examples of mapped landforms at the study area. The terrain views are produced using the shaded relief surface model derived from a digital elevation model (cell size $=2 \mathrm{~m}$; sun angle $=45^{\circ}$, azimuth $\left.=315^{\circ}\right)(\mathrm{NLS} 2008-2018)$.

\section{Materials and Methods}

\section{Background}

Geoconservation (i.e. geodiversity conservation) is increasing across Europe through national-level initiatives (Burek \& Prosser, 2008). Internationally, UNESCO Global Geoparks aim to increase awareness of the Earth's unique geoheritage and its importance for nature and cultures through scientific research, education and geotourism (McKeever, Zouros, \& Patzak, 2010). Our study area is within Rokua UNESCO

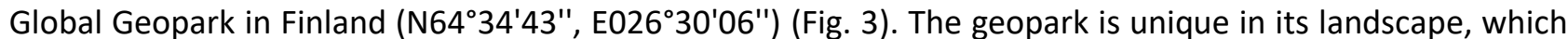
is formed during and after the latest deglaciation, and includes a number of impressive bedrock sites and a wide range of landforms such as bogs, gullies, kettle holes and dunes. The $1326 \mathrm{~km}^{2}$ Geopark area is comprised of three different landscape areas: the Rokua esker and dune area (Rokuanvaara -area), River Oulujoki Valley and Lake Oulujärvi. Portions of the Geopark are also included in NATURA 2000, Finnish National Park, National Esker Area and Mires and Shoreline conservation programmes for their geomorphological, ecological and cultural values. 


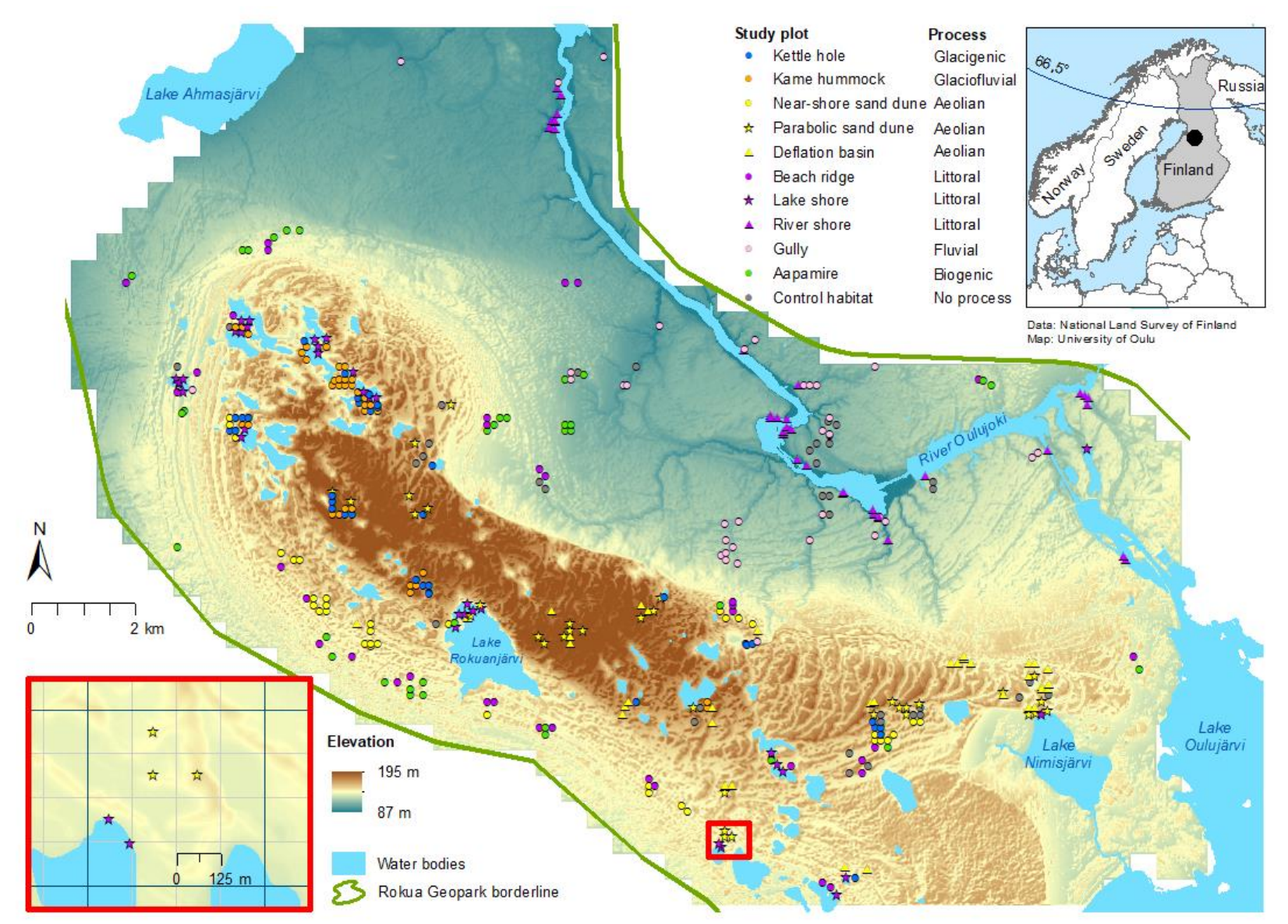

Figure 3. Map of the study area and the locations of studied $1-\mathrm{m}^{2}$ vegetation plots that were included in the analyzed dataset $(n=385)$. Zoomed in the left is an example of the grid approach that was used in the determination of the 1- $\mathrm{m}^{2}$ vegetation plots, where richness and cover of vascular plants was recorded. We constructed a grid (cell size $500 \times 500 \mathrm{~m}$ ) over the study area which was further subdivided to $125 \times 125 \mathrm{~m}$ cells. The center of each $125 \times 125 \mathrm{~m}$ cell determined the location of the $1-\mathrm{m}^{2}$ vegetation plot. If a located inventory site was on a water body or human-disturbed area, the site was relocated to the nearest undisturbed location.

Rokua UNESCO Global Geopark is located in the middle boreal vegetation zone with characteristics from both southern and northern boreal zones. Coniferous trees including Scotch pine (Pinus sy/vestris) and Norway spruce (Picea abies) dominate as tree species. Twigs, such as lingonberry (Vaccinium vitis-idaeae) and Labrador tea (Rhododendron tomentosum), dominate the field layer. The bedrock of the study area is mostly igneous migmatite granite gneiss, granite and schists (Aartolahti, 1973; Huttunen et al., 2013) which is covered by soils mostly composed of glaciofluvial deposits such a fine- or coarse-grained sand or silt (Aartolahti, 1973; Ala-aho, Rossi, Isokangas, \& Kløve, 2015). The lake and river system of the study area consists mainly of the River Oulujoki and lakes or ponds of various sizes. Mean annual temperature of the study area during the period $1981-2010$ was $1.9^{\circ} \mathrm{C}$ and mean annual precipitation was $620 \mathrm{~mm}$, with low monthly variation (mean monthly precipitation ca. $50 \mathrm{~mm}$ ). Snow is typically present in the area from October to April (Pirinen et al., 2012).

\section{Biodiversity and landform data}

Terrestrial vascular plant species data (a total of $15351-\mathrm{m}^{2}$ vegetation quadrats) were collected during the field inventories in summer 2012 with the aim to catalog the data from predetermined, randomly selected sites from the three landscape areas of Rokua UNESCO Global Geopark. We facilitated the accessibility of 
the sites by using a grid approach to determine the location of the 1- $\mathrm{m}^{2}$ vegetation quadrats (Fig. 3). We constructed a grid (cell size $=500 \times 500 \mathrm{~m}$ ) over the whole study area and then randomly selected 65 grid cells. These grid cells were subdivided to $125 \times 125 \mathrm{~m}$ cells and the center of each cell determined the inventory site (i.e. the location of the 1- $\mathrm{m}^{2}$ vegetation plot, located with a GPS device). If an inventory site was on a water body or human-disturbed area (e.g. a peat production area or a cultivated field) according to aerial images (NLS 2010a), base maps (NLS 2010b) and land use data (CORINE 2006), the site was relocated to the nearest undisturbed location.

Each inventoried $1-\mathrm{m}^{2}$ vegetation quadrat was classified either as landform site $(n=699)$ or as a control habitat (i.e. no distinguishable landform present, $n=836$ ). Geomorphological or geological formations that were geographically too large relative to the scale of our study (e.g. the Rokuanvaara esker system) were not considered as distinct landforms. The suitable landforms were identified using field collected data, remotely sensed data, existing map layers and data from prior studies. Remote sensing data included aerial images (NLS 2010a) and LiDAR data based DEMs (NLS 2008-2018). Map data included base maps (NLS 2010b) and soil data (GSF 2015). Prior studies in the area were also harvested for landform information (e.g. Jalas 1953; Aartolahti 1973; Kløve, Ala-aho, Okkonen, \& Rossi, 2012). We identified ten landform types formed by different earth surface processes: kettle holes (glacigenic), kame-hummocks (glaciofluvial), nearshore dunes, parabolic dunes and deflation basins (aeolian), beach ridges, lake shores and river shores (littoral), gullies (fluvial) and aapa mires (biogenic) (Fig. $1 \& 2$; Table 1). For comparability, we set the sample size for each landform at 35 , which was the maximum number of kettle hole and river shore sites. For those landforms that had more studied plots (from 37 to 110 plots), 35 plots were randomly sampled. A control dataset of 35 plots, not located on any distinct landform were used to test the null hypothesis. Consequently, a total of 385 plots were selected for the analysis.

We determined biodiversity using measures of species richness, rarity and commonly used diversity indices (Table 2). We calculated alpha diversity using the mean vascular plant species richness, inverse Simpson diversity index and Shannon's diversity index for each landform and each study plot (Tuomisto, 2010; Table 2). As a measure of alpha diversity, we also calculated rarity-weighted richness (RWR) (Williams et al., 1996; Albuquerque \& Beier, 2015; Table 2). Gamma diversity was quantified as the number of vascular plant species recorded for each landform type in total, and with Shannon's and inverse Simpson indices (Table 2). We calculated the contribution of single sites to overall beta diversity on studied plots (patterns in local contribution to beta diversity, $L C B D$ ), to identify ecologically unique landforms in relation to other landforms in the studied data (Legendre \& De Cáceres, 2013; Heino \& Grönroos, 2017). LCBD mirrors the relative contribution of individual sampling units to beta diversity, and high LCBD value of a site suggests that the site includes an exclusive community composition across the whole data set. To calculate the LCBD values for each study plot, we used Hellinger-transformed abundance data and the function beta.div in the R script written by Legendre and De Cáceres (2013) (Table 2). In addition, we calculated beta diversity with Biodiversity Assessments Tools package (Cardoso et al., 2015) beta.multi function which can be used to assess total beta diversity, that can be further separated to species richness and species replacement components (see Appendix S1 in Supporting Information for further details).

\section{Statistical analysis}

We tested the difference between indices of alpha diversity and LCBD (which had unique values for each studied plot, contrary to measures of gamma diversity) in the control habitat and distinct landforms with the non-parametric Mann-Whitney U-test for two independent samples (Ruxton, 2006). This test assesses the likelihood that a randomly selected value from one sample will be less or greater than a randomly selected value from a second sample (Mann \& Whitney, 1947). A Bonferroni correction ( $p$-value multiplied by the number of tests performed) was used to control potential Type 1 error, i.e. concluding that a statistically significant difference is present when it is not (Armstrong, 2014). 
Table 1. Description of the landforms included in this study and their characteristics.

\begin{tabular}{|c|c|c|c|c|}
\hline Landform & Definition & $\begin{array}{l}\text { Special characteristics } \\
\text { (variability in soil } \\
\text { moisture conditions / } \\
\text { microclimate / } \\
\text { microtopography) }\end{array}$ & $\begin{array}{l}\text { General } \\
\text { soil } \\
\text { moisture } \\
\text { level }\end{array}$ & $\begin{array}{l}\text { Expected to } \\
\text { increase } \\
\text { vascular plant } \\
\text { biodiversity }\end{array}$ \\
\hline Kettle hole & $\begin{array}{l}\text { A (circular) depression formed by } \\
\text { melt of a block of (buried) glacier } \\
\text { ice. }\end{array}$ & $\begin{array}{l}\text { High / high / } \\
\text { moderate }\end{array}$ & Moderate & Moderate \\
\hline $\begin{array}{l}\text { Kame- } \\
\text { hummock }\end{array}$ & $\begin{array}{l}\text { A hummock (or hill) composed of } \\
\text { sand and gravel laid down by } \\
\text { glacial meltwater. }\end{array}$ & $\begin{array}{l}\text { Low / moderate / } \\
\text { moderate }\end{array}$ & Low & Low \\
\hline $\begin{array}{l}\text { Near-shore } \\
\text { sand dune }\end{array}$ & $\begin{array}{l}\text { A gently sloping ridge formed by } \\
\text { wind-deposited sand close to } \\
\text { beach (here paleo-beach). }\end{array}$ & $\begin{array}{l}\text { Low / moderate / } \\
\text { moderate }\end{array}$ & Low & Low \\
\hline $\begin{array}{l}\text { Parabolic sand } \\
\text { dune }\end{array}$ & $\begin{array}{l}\text { A U- or V-shaped ridge formed by } \\
\text { wind-deposited sand. }\end{array}$ & Low / high / high & Low & Low \\
\hline $\begin{array}{l}\text { Deflation } \\
\text { basin }\end{array}$ & $\begin{array}{l}\text { A depression formed by wind } \\
\text { erosion (here mostly inactive and } \\
\text { vegetated). }\end{array}$ & Moderate / low / low & Moderate & Moderate \\
\hline Beach ridge & $\begin{array}{l}\text { A gently sloping sand ridge formed } \\
\text { by wave action. }\end{array}$ & Low / low / low & Low & Low \\
\hline Lake shore & $\begin{array}{l}\text { A marginal zone above the mean } \\
\text { water level of a lake (horizontally < } \\
5 \mathrm{~m} \text { away from the water line). }\end{array}$ & $\begin{array}{l}\text { High / low / } \\
\text { moderate }\end{array}$ & High & High \\
\hline River shore & $\begin{array}{l}\text { A marginal zone above the mean } \\
\text { water level of a river (horizontally < } \\
5 \mathrm{~m} \text { away from the water line). }\end{array}$ & $\begin{array}{l}\text { High / low / } \\
\text { moderate }\end{array}$ & High & High \\
\hline Gully (ravine) & $\begin{array}{l}\text { A (steep-sided) channel formed by } \\
\text { fluvial erosion. }\end{array}$ & High / high / high & High & High \\
\hline Aapa mire & $\begin{array}{l}\text { A boreal mire complex with flarks } \\
\text { (i.e. wet depressions) and peat } \\
\text { strings. }\end{array}$ & $\begin{array}{l}\text { Moderate / moderate } \\
\text { / moderate }\end{array}$ & High & Moderate \\
\hline
\end{tabular}


Table 2. The measures of biodiversity as levels of alpha, beta and gamma diversity. The diversity indices are inverse Simpson diversity index (Simpson, 1949; Oksanen, 2015), Shannon H' diversity index (Shannon \& Weaver, 1949; Oksanen, 2015), beta diversity (Legendre \& De Cáceres, 2013) and rarity-weighted richness (Williams et al., 1996; Albuquerque \& Beier, 2015).

\begin{tabular}{lc|l|l|l}
$\begin{array}{l}\text { Measure of } \\
\text { biodiversity }\end{array}$ & $\begin{array}{l}\text { Level / } \\
\text { abbreviation }\end{array}$ & Description & Formula & $\begin{array}{l}\text { Details of the } \\
\text { formula }\end{array}$ \\
$\begin{array}{l}\text { Species } \\
\text { richness }\end{array}$ & $\alpha$ & $\begin{array}{l}\text { Average (arithmetic mean) of } \\
\text { vascular plant species number in } \\
\text { each landform type. }\end{array}$ & $\bar{x}=\frac{1}{n} \sum_{i=1}^{n} x_{\bar{i}}$ & $\begin{array}{l}n \text { is the number } \\
\text { of values } x\end{array}$ \\
& $\gamma$ & $\begin{array}{l}\text { Total number of vascular plant } \\
\text { species in each landform type. }\end{array}$ &
\end{tabular}

\begin{tabular}{|c|c|c|c|c|}
\hline \multirow[t]{2}{*}{$\begin{array}{l}\text { Shannon } \mathrm{H}^{\prime} \\
\text { diversity } \\
\text { index }\end{array}$} & $\alpha$ & $\begin{array}{l}\text { The average value of the index } \\
\text { in each landform type. }\end{array}$ & $H^{\prime}=-\sum_{i=1}^{s} p_{i} \ln p_{i}$ & $\begin{array}{l}p_{i} \text { is the } \\
\text { proportion of } \\
\text { species } i \\
\mathrm{~S} \text { is the number } \\
\text { of species }\end{array}$ \\
\hline & $v$ & $\begin{array}{l}\text { The value of the index calculated } \\
\text { only with the values of each } \\
\text { landform. }\end{array}$ & & \\
\hline \multirow[t]{2}{*}{$\begin{array}{l}\text { Inverse } \\
\text { Simpson } \\
\text { diversity } \\
\text { index }\end{array}$} & $\alpha$ & $\begin{array}{l}\text { The average value of the index } \\
\text { in each landform type. }\end{array}$ & $D=\frac{1}{\sum_{i=1}^{S} p_{i}^{2}}$ & $\begin{array}{l}p_{i} \text { is the } \\
\text { proportion of } \\
\text { species } i \\
\mathrm{~S} \text { is the number } \\
\text { of species }\end{array}$ \\
\hline & $\gamma$ & $\begin{array}{l}\text { The value of the index calculated } \\
\text { only with the values of each } \\
\text { landform. }\end{array}$ & & \\
\hline
\end{tabular}

\begin{tabular}{|c|c|c|}
\hline $\begin{array}{l}\text { Patterns in } \\
\text { local } \\
\text { contribution } \\
\text { to beta } \\
\text { diversity }\end{array}$ & $\beta / \mathrm{LCBD}$ & $\begin{array}{l}\text { Beta diversity values were } \\
\text { calculated in R with beta.div } \\
\text { function, which calculates the } \\
\text { contribution of single sites to } \\
\text { overall beta diversity on all of } \\
\text { the studied plots. }\end{array}$ \\
\hline
\end{tabular}

\section{Rarity- $\quad \alpha /$ RWR $\quad$ The sum of the rarity values}

weighted

from each species recorded.

richness

Rarity value is the inverse

number of quadrats in which the

$R W R=\sum_{1}^{n}\left(1 / c_{i}\right) \quad \begin{aligned} & c_{i} \text { is the } \\ & \text { number of } \\ & \text { quadrats }\end{aligned}$

species occur. Landforms

occupied by

containing rarer species have

species $i$

higher RWR values. 
To examine the variation in the topographical and soil moisture conditions between the distinct landforms and control habitat, we calculated DEM-derived slope angle $\left({ }^{\circ}\right.$ ), topographical wetness index (TWI) and a measure of theoretical solar radiation (SRAD, $\mathrm{Mj} \mathrm{cm}^{-2}$ year $^{-1}$ ) for each plot. We used boxplots and MannWhitney U-test to compare these topographical characteristics among landforms and to compare the landforms and the control sites. Furthermore, we used Spearman's rank order correlation $\left(r_{s}\right)$ and generalized additive models (GAMs) to explore the relationship between topographical and biodiversity variables (species richness, diversity indices, rarity-weighted richness and LCBD) (see Appendix S2 in Supporting Information for further details of these analyses and their results).

\section{Results}

We found 102 vascular plant species from 38 families from the plots included in the analysis $(n=385)$ (see Appendix S3 in Supporting Information for further details of the species frequencies). The heathers (Ericaceae family) were most common in the data and lingonberry (Vaccinium vitis-idaea) was the most common species (Fig. 4). Alpha diversity showed the same pattern regardless of which measure was used (species richness, Shannon's and inverse Simpson diversity indices and RWR) (Fig. 4). Alpha diversity was highest in gullies, where average species richness was 6.6. River shores and aapa mires had also high alpha diversity values (Fig. 4). Near-shore dunes had the lowest mean species richness (2.3) while the control sites had the lowest diversity indices at the level of alpha diversity (minimum values of the population). RWR was approximately twenty times larger at river shores and gullies than it was in near-shore dunes, parabolic dunes, beach ridges and control habitat, which had the smallest RWR values. The difference in alpha diversity between considered landforms and control habitat was, according to the Mann-Whitney Utest, statistically significant $(p \leq 0.05)$ for kettle holes, beach ridges, lake and river shores, gullies and aapa mires (mean species richness and diversity indices), and for deflation basins (diversity indices) (Fig. 4). In addition, five landforms that had the highest RWR values (kettle holes, lake and river shores, gullies and aapa mires) differed statistically significantly from the control habitat (Fig. 4).

Gamma diversity had the highest values in gullies (total number of species 59) and river shores (total number of species 57) (Fig. 4). In addition, kettle holes had high diversity index values. Gamma diversity was lowest in near-shore dunes and control habitat, where the total number of species was seven and 15, respectively. Beta diversity, measured as $\angle C B D$, was highest in aapa mires, and also high in river shores, gullies, lake shores and kettle holes. LCBD was lowest in beach ridges, control sites and kame hummocks (Fig. 4). LCBD had a statistically significant difference between landforms and control habitat in kettle holes, lake and river shores, gullies and aapa mires (Fig. 4). Total beta diversity had similar patterns, with replacement as the dominant component in five landforms (kettle holes, lake shores, river shores, gullies and aapa mires; these landforms had also the highest total beta diversity). Beta diversity explained by species loss/gain (richness differences) was dominant in the other five landforms and control habitat (Appendix S1).

From all of the examined landforms, near-shore dunes had the lowest values in the case of species richness, RWR and LCBD (Fig. 4). Control habitat received the lowest Shannon and Simpson values. Gullies had highest diversity values in the case of six diversity measures out of eight, while river shores had the highest values of RWR and aapa mires had the highest LCBD values. Beta diversity had rather uniform patterns with alpha and gamma diversity, with few exceptions. The measures of species diversity correlated moderately or strongly with each other. LCBD had the weakest correlations with the other measures (see Table S2.2 in in Supporting Information for further details of the correlations). 


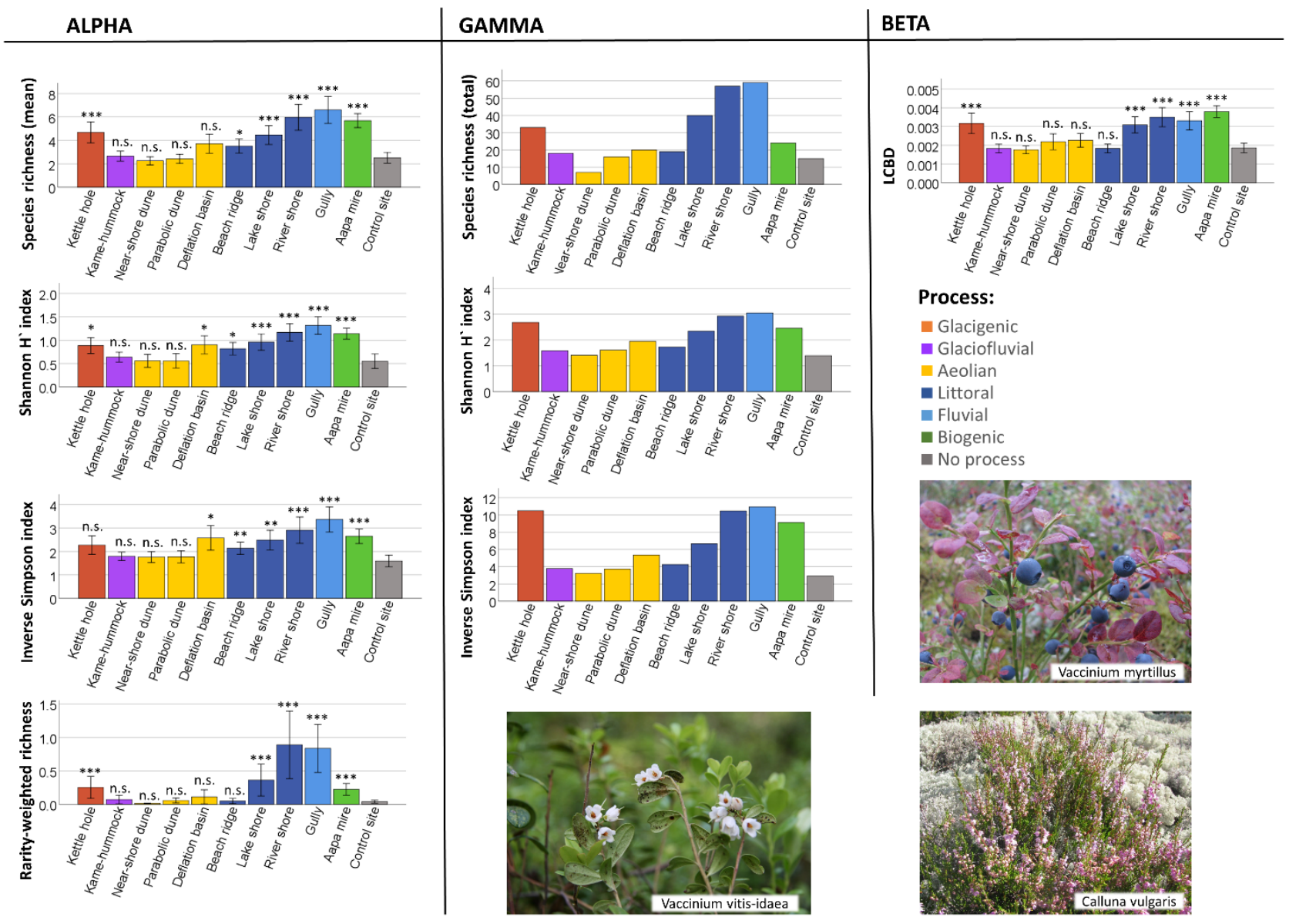

Figure 4. Measures of vascular plant diversity (y-axis) for each landform type, grouped by the level of diversity (alpha, gamma and beta). Error bars are displayed at the level of $95 \%$ confidence intervals for the measures that are calculated as mean values of single plot values (alpha and beta measures; $n=35$ at each landform and control site). LCBD refers to patterns in local contribution to beta diversity. The statistical significance between study plots on different landforms and plots on control habitat (measured with MannWhitney U-test) is illustrated with asterisks: $p$-value $\leq 0.001\left(^{* * *}\right), p \leq 0.01(* *)$ and $p \leq 0.05(*)$. The $p$-values are Bonferroni-corrected by multiplying the original $p$-value with the amount of tests $(n=10)$ conducted. Lingonberry (Vaccinium vitis-idaea) was the most common species in the data (occurred at 307 of the 385 plots). Bilberry (Vaccinium myrtillus) and heather (Calluna vulgaris) were second most common with 151 observations.

DEM-derived slope angle was generally higher on landforms than on control sites. In addition, slope angle varied in some extent among landforms (highest at river shores, parabolic sand dunes and gullies) (Fig. S2.1). The variation between TWI, and especially between SRAD at different landforms was rather low (Fig. S2.2 and S2.3). The correlations between DEM-derived topographical variables and biodiversity variables were weak $\left(r_{s}<|0.16|\right)$ and the GAMs explained clearly less than $10 \%$ of the variation in the biodiversity measures (Table S2.2 and S2.3).

\section{Discussion}

Our results indicate that landforms are important elements for vascular plant diversity. We found that almost all distinct landforms harbored greater vascular plant diversity than the control sites, and there was notable variation in the diversity between different landforms. Although there were some differences, beta 
diversity patterns were rather comparable with alpha and gamma diversity measures (Fig. 4). DEM-based topographic variables did not succeed well in distinguishing biodiversity between landforms (slope angle as an exception) or as predictors of alpha and beta level biodiversity measures (Appendix S2). These findings support previous research results where the role of landforms and varying physical landscape has proved to be important for biodiversity (Lawler et al., 2015; Bailey et al., 2017). Our findings support the CNS principles following the legacy of von Humboldt and encourage conservation practitioners to incorporate and utilize landform and geodiversity information in decision making.

\section{Landforms promote biodiversity and have unique diversity patterns}

Our first hypothesis $\left(\mathrm{H}_{1}\right)$ stated that biodiversity is higher on distinct landforms compared to the control sites. The results of this study support this at different levels and using several biodiversity measures (Fig. 4). The difference in alpha and beta diversity between landforms and the control habitat is statistically significant in most cases, i.e. biodiversity is significantly smaller in the control habitat than on landforms (Fig. 4). As an exception, control sites tended to be more diverse than parabolic or near-shore sand dunes based on alpha and gamma diversity metrics. This is probably because sand dunes are located in dry lichencovered forests with low soil moisture content in sandy soil (Chipman \& Johnson, 2002; Tilk et al., 2011; Ujházy et al., 2011; Fig. 1). Sand dunes are also highly susceptible to natural and unnatural erosion, which is generally seen as a factor that limits species richness (Antonelli et al., 2018).

According to our results, biodiversity varies substantially between different landforms, regardless of the measure used. This is in-line with our second hypothesis $\left(\mathrm{H}_{2}\right)$. Although direct species richness measures and Shannon's and inverse Simpson diversity indices differ in their theoretical framework and in their calculation methods, their variation among landforms is similar both at alpha and gamma levels (Fig. 4). As expected, biodiversity is generally highest in moisture-rich gullies and river shores (Table 1; Fig. 4). They are the most diverse landforms for each alpha and gamma diversity measure, which reflects their importance both for local and regional-scale biodiversity. RWR values of river shores and gullies are considerably higher than the RWR of other landforms or control sites, meaning that they contain the most pronounced number of rare species in our data (Fig. 4). Lake shores are among the most diverse landforms trough the results, but are not as high in biodiversity as river shores (Fig. 4). This is in-line e.g. with Bailey et al. (2017), who found out that valley coverage and river length had positive contributions for vascular plant species richness, whereas lake area tended to be less important.

The variations in soil moisture availability and the proximity of ground water have great influence in vascular plant diversity (Jansson et al., 2007). For instance, deflation basins have the largest alpha, gamma and beta diversity of aeolian landforms in the study (and intermediate values compared to other landforms). Although they are quite flat and their surface-layers consists mostly of coarse-grained sand that filters water effectively, they vary substantially in their moisture level, which is directly related to the availability of different microhabitats and to the variation in their vascular plant diversity (Tilk et al., 2011; Ujházy et al., 2011; Moeslund et al., 2013; Lenoir et al., 2017; Table 1).

\section{Diversity levels: alpha, beta and gamma}

Beta diversity patterns were rather comparable with alpha and gamma diversity, which contradicts with the hypothesis $\mathrm{H}_{3}$. The plant diversity of aapa mires (which was the highest in LCBD and high to intermediate at alpha and gamma levels) followed the expectations best (Fig. 4). The total beta diversity of aapa mires is more strongly dependent on the replacement component, meaning that differences in species composition are the main reasons for their high beta diversity (Appendix S1). Aapa mires have high soil moisture and variable microtopography and microclimate owing to their flark-string patterns (Lindholm \& Heikkilä, 2006; Fig. 2). This variation creates unique growing conditions and habitats for different species. Microhabitats and microclimates that create heterogeneous niche-space are important determinants of biodiversity (Lundholm, 2009; Jones, Szyska, \& Kessler, 2011; Lembrechts et al. 2018) and buffer species against climate change by providing local climatic options (Anderson et al., 2014; Lenoir et al., 2017). 
According to the results, kettle holes have rather high alpha, gamma and beta diversity values (Table 1; Fig. 4). Their gamma and beta diversity values are slightly higher than the alpha diversity values, reflecting their role for regional-scale diversity and taxonomic uniqueness among the studied kettle holes and control sites (which is also visible in the high replacement-component values of beta diversity, see Appendix S1). Kettle holes, as well as other depression-like landforms, can maintain varying types of environments, e.g. dry and sunny, south facing slopes, shady and moist north-facing slopes and moist bottoms, and vary in their topography, which creates different microhabitats and microclimates and thus promotes vascular plant diversity (Aartolahti, 1973; Jones et al., 2011).

Parabolic dunes have generally low alpha and gamma diversity, but their LCBD values are intermediate (approximately at the same level as deflation basins) (Fig. 4). Thus, although they are dry, sandy environments that are susceptible to erosion, they still have value in maintaining somewhat unique species compositions. These results are partly in-line with Legendre and De Cáceres (2013) who state that sites with high LCBD values are commonly not species rich, although they are ecologically unique. This observation supports the use of LCBD in conservation: in addition to having species-rich sites as a conservation goal, also the ecological uniqueness of sites should be taken into account (Heino \& Grönroos, 2017).

\section{Landforms in conservation and land use planning}

Knowledge of the relationships between biodiversity and landforms may be applied to conservation and land-use planning. Information on landforms is relatively easy to acquire across biomes from LiDAR data based DEMs and geomorphological maps, which can be further complemented with fieldwork. Specific information on the biodiversity of different landforms could be very profitable, both economically and biogeographically. For instance, sand (the main soil type in our study) is one of the most extracted materials worldwide and its demand will increase in coming years. This trend is putting strain on limited sand deposits and formations, degrading biodiversity at the extraction areas (Torres, Brendt, Lear, \& Liu, 2017). Our results indicate that landforms that harbor low beta diversity (LCBD) but are common, such as near-shore dunes (and of which the total beta diversity value is mainly explained by richness differences, as in the case of dunes, see Appendix S1), could be partially used for sand extraction purposes without necessarily risking the total value of that landform for the biodiversity in the extraction area (see e.g. Socolar et al., 2016). However, it must be noticed that the conservational status or the endemism of the species present must also be taken into account (Myers et al., 2000).

Landforms often have unique but type-specific material, microclimatic and hydrological characteristics that are overlooked if abiotic diversity is observed only with one or two factors, such as topographic parameters (Lawler et al., 2015; Bailey et al., 2017). In our results, DEM-based topographic variables at 10-m resolution alone did not succeed well in distinguishing biodiversity of the area (Appendix S2), although topographyrelated microhabitats and -climates are shown to drive plant diversity (Lenoir et al., 2016; Lembrechts et al., 2018). To examine the role of microhabitats and -climates more closely, more exact data on microtopography at the studied landforms would be needed. To gain a wider perspective, more research is required on the relationship between landforms, their topographic conditions and biodiversity in different biomes, at different scales and for both common and threatened species. This information could substantially improve decision-making in conservation planning and management. We promote the incorporation of geodiversity into nature conservation management both for its own geoconservational value and because it supports biodiversity.

A number of different approaches have been developed to evaluate and value landforms (Reynard, 2009; Brilha, 2016). However, biodiversity or ecological criteria have been taken into account in only some of these. Our results reveal the importance not only to include plot-scale ecological data in the landform evaluation processes but also to include site-scale landform data in ecological evaluations. In this study we focused on the diversity of vascular plants because their species richness has been proven to be a good indicator for the diversity of other taxa (Nilsson \& Ericson, 1997; Pharo et al., 1999). Furthermore, species 
richness is one of the most frequently used measures of biodiversity and species are typically the units of conservation (Lindemayer \& Burgman, 2005; Antonelli et al., 2018).

Although estimates of species richness are popularly used and considered as quite reliable, they are known to be affected for instance by area, scale and intensity of sampling, taxonomic grouping and the estimation methods (Fleishman et al., 2006). Using species richness on its own can lead to poor management practices, such as favoring edge habitats over interior habitats. Thus, a wider array of principles and measures are needed to ensure the versatility and the quality of conservation management. Based on this study, the inclusion of cross-habitat or beta diversity metrics provide valuable information in addition to local and regional-scale diversity metrics. For instance, most of the landforms in the studied data have unique taxonomic patterns (i.e. higher LCBD), when compared to control sites (Fig. 4). This could mean that conservation reserves that capture the full range of the landforms that have higher LCBD than control sites, probably capture the most of the vascular plant richness in the area. In addition to species richness metrics, species endemism, species functional significance and the resilience of the area towards climate change are worth of considering in conservation area design and in further local and regional scale geodiversity studies (Fleishman et al., 2006; Knudson et al., 2018).

\section{Conclusions}

To conclude, we found support for the Conserving Nature's Stage framework and for the use of local-scale geodiversity information (here, distinct landforms) in biodiversity assessments. Our results support the use of landform data, which can be cost-effectively acquired using geospatial data technologies (e.g. LiDAR data based DEMs) and from published geomorphological maps in addition to fieldwork. According to the results, landforms underpin plant diversity at alpha, beta and gamma levels. Especially, landforms that are moist and hydrologically variable (such as gullies and river shores) have high biodiversity. In addition, microhabitats and microclimates that different landforms provide seem to be important in structuring different levels of diversity. Although distinct landforms generally had higher plant diversity than control sites, sand dunes obtained low diversity values. Aapa mires were especially high in their beta diversity, reflecting their unique taxonomic conditions. DEM-based topographic variables did not succeed well in distinguishing biodiversity between landforms (slope angle as an exception) or as predictors of biodiversity measures. In the future, the local-scale geodiversity, based on landforms or other geofeatures, should be examined more closely in different geographical locations, with different biodiversity measures and with different taxonomic groups to gain more comprehensive understanding on the relationship between abiotic and biotic environment.

\section{References}

Aartolahti, T. (1973) Morphology, vegetation and development of Rokuanvaara, an esker and dune complex in Finland. Fennia vol 127. Societas geographica Fenniae, Helsinki.

ACIA (2005) Arctic Climate Impact Assessment.

Ala-aho, P., Rossi, P.M., Isokangas, E., \& Kløve, B. (2015) Fully integrated surface-subsurface flow modelling of groundwater-lake interaction in an esker aquifer: Model verification with stable isotopes and airborne thermal imaging. Journal of Hydrology, 522, 391-406.

Albano, C.M. (2015) Identification of geophysically diverse locations that may facilitate species' persistence and adaptation to climate change in the southwestern United States. Landscape Ecology, 30, 1023-1037. 
Albuquerque, F. \& Beier, P. (2015) Rarity-weighted richness: A simple and reliable alternative to integer programming and heuristic algorithms for minimum set and maximum coverage problems in conservation planning. PLoS ONE, 10, 1-7.

Alexandrowicz, Z. \& Margielewski, W. (2010) Impact of mass movements on geo- and biodiversity in the Polish Outer (Flysch) Carpathians. Geomorphology, 123, 290-304.

Anderson, M.G., Clark, M., \& Sheldon, A.O. (2014) Estimating Climate Resilience for Conservation across Geophysical Settings. Conservation Biology, 28, 959-970.

Antonelli, A., Kissling, W.D., Flantua, S.G.A., Bermúdez, M.A., Mulch, A., Muellner-Riehl, A.N., Kreft, H., Linder, H.P., Badgley, C., Fjeldså, J., Fritz, S.A., Rahbek, C., Herman, F., Hooghiemstra, H., \& Hoorn, C. (2018) Geological and climatic influences on mountain biodiversity. Nature Geoscience, 11, 718-725.

Armstrong, R.A. (2014) When to use the Bonferroni correction. Ophthalmic \& physiological optics : the journal of the British College of Ophthalmic Opticians (Optometrists), 34, 502-508.

Bailey, J.J., Boyd, D.S., \& Field, R. (2018) Models of upland species' distributions are improved by accounting for geodiversity. Landscape Ecology, 1-17.

Bailey, J.J., Boyd, D.S., Hjort, J., Lavers, C.P., \& Field, R. (2017) Modelling native and alien vascular plant species richness: At which scales is geodiversity most relevant? Global Ecology and Biogeography, 26, 763776.

Beier, P., Hunter, M.L., \& Anderson, M. (2015) Special Section: Conserving Nature's Stage. Conservation Biology, 29, 613-617.

Bétard, F. (2013) Patch-Scale Relationships Between Geodiversity and Biodiversity in Hard Rock Quarries: Case Study from a Disused Quartzite Quarry in NW France. Geoheritage, 5, 59-71.

Brilha, J. (2016) Inventory and Quantitative Assessment of Geosites and Geodiversity Sites: a Review. Geoheritage, 8, 119-134.

Burek, C. V. \& Prosser, C.D. (2008) The history of geoconservation: an introduction. Geological Society, London, Special Publications, 300, 1-5.

Butchart, S.H.M., Walpole, M., Collen, B., et al. (2010) Global biodiversity: Indicators of recent declines. Science, 328, 1164-1168.

Cardoso, P., Rigal, F., \& Carvalho, J.C. (2015) BAT - Biodiversity Assessment Tools, an R package for the measurement and estimation of alpha and beta taxon, phylogenetic and functional diversity. Methods in Ecology and Evolution, 6, 232-236.

Carson, J.K., Campbell, L., Rooney, D., Clipson, N., \& Gleeson, D.B. (2009) Minerals in soil select distinct bacterial communities in their microhabitats. FEMS Microbiology Ecology, 67, 381-388.

Chipman, S. \& Johnson, E. (2002) Understory vascular plant species diversity in the mixedwood boreal forest of western Canada. Ecological Applications, 12, 588-601. 
CORINE (Coordination of Information on the Environment -Land Cover) (2006). CORINE land cover, 25x25m. https://avaa.tdata.fi/web/paituli/latauspalvelu

Dobrowski, S.Z. (2011) A climatic basis for microrefugia: the influence of terrain on climate. Global Change Biology, 17, 1022-1035.

Erikstad, L. (2013) Geoheritage and geodiversity management - the questions for tomorrow. Proceedings of the Geologists' Association, 124, 713-719.

Eurola, S. \& Huttunen, A. (2006) Mire plant species and their ecology in Finland. Finland, Land of Mires pp. 127-144. Finnish Environment Institute, Vammala.

Fleishman, E., Noss, R.F., \& Noon, B.R. (2006) Utility and limitations of species richness metrics for conservation planning. Ecological Indicators, 6, 543-553.

Gray, M. (2013) Geodiversity: valuing and conserving abiotic nature. Wiley-Blackwell, Chichester.

GSF (Geological Survey of Finland) (2015). Superficial deposits 1:20,000 / 1:50,000.

https://hakku.gtk.fi/en/locations/search

Heino, J. \& Grönroos, M. (2017) Exploring species and site contributions to beta diversity in stream insect assemblages. Oecologia, 183, 151-160.

Hjort, J., Gordon, J.E., Gray, M., \& Jr, M.L.H. (2015) Why geodiversity matters in valuing nature ' s stage. Conservation Biology, 29, 630-639.

Hjort, J., Heikkinen, R.K., \& Luoto, M. (2012) Inclusion of explicit measures of geodiversity improve biodiversity models in a boreal landscape. Biodiversity and Conservation, 21, 3487-3506.

Hjort, J. \& Luoto, M. (2010) Geodiversity of high-latitude landscapes in northern Finland. Geomorphology, $115,109-116$.

Humboldt, A. von (1807) Ansichten der Natur: mit wissenschaftlichen Erläuterungen: beide Teile in enem Bande. I. G. Cotta'schen Buchhandlung, Stuttgart.

Huttunen, T., Hyvärinen, J., Kokkonen, J., Kousa, J., Nenonen, J., Rönty, H., Saarelainen, J., Tervo, T., \& Väänänen, T. (2013) Rokua Geopark: Heritage of the Ice Age. Geological outdoor guide. Geological Survey of Finland, Kuopio.

IPCC (2018) Global Warming of $1.5^{\circ} \mathrm{C}$, an IPCC special report on the impacts of global warming of $1.5^{\circ} \mathrm{C}$ above pre-industrial levels and related global greenhouse gas emission pathways, in the context of strengthening the global response to the threat of climate change.

Jačková, K. \& Romportl, D. (2008) The Relationship Between Geodiversity and Habitat Richness in Šumava National Park and Křivoklátsko PLA (Czech Republic): A Quantitative Analysis Approach. Journal of Landscape Ecology, 1, 23-38.

Jalas, J. (1953) Rokua. Suunnitellun kansallispuiston kasvillisuus ja kasvisto. Silva Fennica, 81, 1-97.

Jansson, R., Laudon, H., Johansson, E., \& Augspurger, C. (2007) The importance of groundwater discharge for plant species number in riparian zones. Ecology, 88, 131-139. 
Jedicke, E. (2001) Biodiversität, Geodiversität, Ökodiversität. Kriterien zur Analyse der Landschaftsstruktur ein konzeptioneller Diskussionsbeitrag. Naturschutz und Landschaftsplanung, 33, 59-68.

Jones, M.M., Szyska, B., \& Kessler, M. (2011) Microhabitat partitioning promotes plant diversity in a tropical montane forest. Global Ecology and Biogeography, 20, 558-569.

Kalliola, R. \& Puhakka, M. (1988) River Dynamics and Vegetation Mosaicism: A Case Study of the River Kamajohka, Northernmost Finland. Journal of Biogeography, 15, 703.

Kløve, B., Ala-aho, P., Okkonen, J., \& Rossi, P. (2012) Possible effects of climate change on hydrogeological systems: results from research on Esker aquifers in norhtern Finland. Climate change effects on groundwater resources: a global synthesis of findings and recommendations pp. 305.

Knudson, C., Kay, K., \& Fisher, S. (2018) Appraising geodiversity and cultural diversity approaches to building resilience through conservation. Nature Climate Change, 8, 678-685.

Kougioumoutzis, K. \& Tiniakou, A. (2014) Ecological factors driving plant species diversity in the South Aegean Volcanic Arc and other central Aegean islands. Plant Ecology \& Diversity, 8, 173-186.

Lawler, J.J., Ackerly, D.D., Albano, C.M., Anderson, M.G., Dobrowski, S.Z., Gill, J.L., Heller, N.E., Pressey, R.L., Sanderson, E.W., \& Weiss, S.B. (2015) The theory behind, and the challenges of , conserving nature 's stage in a time of rapid change. Conservation Biology, 29, 618-629.

Legendre, P. \& De Cáceres, M. (2013) Beta diversity as the variance of community data: dissimilarity coefficients and partitioning. Ecology Letters, 16, 951-963.

Lembrechts, J.J., Nijs, I., \& Lenoir, J. (2018) Incorporating microclimate into species distribution models. Ecography 42, 1-13.

Lenoir, J., Hattab, T., \& Pierre, G. (2017) Climatic microrefugia under anthropogenic climate change: implications for species redistribution. Ecography, 40, 253-266.

Lindemayer, D. \& Burgman, M.A. (2005) Practical conservation biology. CSIRO Publishing.

Lindholm, T. \& Heikkilä, R. (2006) Geobotany of Finnish forests and mires: the Finnish approach. Finlandland of mires The Finnish Environment 26.

Lundholm, J.T. (2009) Plant species diversity and environmental heterogeneity: Spatial scale and competing hypotheses. Journal of Vegetation Science, 20, 377-391.

Magurran, A.E. (2004) Measuring Biological Diversity. Wiley-Blackwell, Oxford.

Malanson, G.P. (1993) Riparian landscapes. Cambridge University Press, USA.

Mann, H.B. \& Whitney, D.R. (1947) On a Test of Whether one of Two Random Variables is Stochastically Larger than the Other. The Annals of Mathematical Statistics, 18, 50-60.

Matthews, T.J. (2014) Integrating Geoconservation and Biodiversity Conservation: Theoretical Foundations and Conservation Recommendations in a European Union Context. Geoheritage, 6, 57-70. 
McKeever, P.J., Zouros, N.C., \& Patzak, M. (2010) The UNESCO Global Network of National Geoparks. The George Wright Forum, 27, 14-18.

Meynard, C.N., Devictor, V., Mouillot, D., Thuiller, W., Jiguet, F., \& Mouquet, N. (2011) Beyond taxonomic diversity patterns: how do $\alpha, \beta$ and $\gamma$ components of bird functional and phylogenetic diversity respond to environmental gradients across France? Global Ecology and Biogeography, 20, 893-903.

Moeslund, J.E., Arge, L., Bøcher, P.K., Dalgaard, T., \& Svenning, J.C. (2013) Topography as a driver of local terrestrial vascular plant diversity patterns. Nordic Journal of Botany, 31, 129-144.

Myers, N., Fonseca, G. a B., Mittermeier, R. a, Fonseca, G. a B., \& Kent, J. (2000) Biodiversity hotspots for conservation priorities. Nature, 403, 853-858.

Najwer, A., Borysiak, J., Gudowicz, J., Mazurek, M., \& Zwoliński, Z. (2016) Geodiversity and Biodiversity of the Postglacial Landscape (Dębnica River Catchment, Poland). Quaestiones Geographicae, 35, 6-28.

Nichols, W.F.., Killingbeckm, K.T., \& August, P. V. (1998) The Influence of Geomorphological Heterogeneity on Biodiversity: II. A Landscape Perspective. Conservation Biology, 12, 371-379.

Nilsson, S.G. \& Ericson, L. (1997) Conservation of plant and animal populations in theory and practice. Ecological Bulletins, 46, 87-101.

NLS (National Land Survey of Finland) (2008-2018). Elevation model $2 \mathrm{~m} \times 2 \mathrm{~m}$. NLS, Helsinki. https://avaa.tdata.fi/web/paituli/latauspalvelu

NLS (National Land Survey of Finland) (2010a). Orthophoto: ortho in colour. NLS, Helsinki. https://tiedostopalvelu.maanmittauslaitos.fi/tp/kartta?lang=en

NLS (National Land Survey of Finland) (2010b). Basic map, background colour 2010, 1:20 000. NLS, Helsinki. https://avaa.tdata.fi/web/paituli/latauspalvelu

Oksanen, J. (2015) Vegan: ecological diversity.

Parks, K.E. \& Mulligan, M. (2010) On the relationship between a resource based measure of geodiversity and broad scale biodiversity patterns. Biodiversity and Conservation, 19, 2751-2766.

Peet, R.K. (1974) The measurement of species diversity. Annual Review of Ecology and Systematics, 5, 285307.

Pharo, E.J., Beattie, A.J., \& Binns, D. (1999) Vascular Plant Diversity as a Surrogate for Bryophyte and Lichen Diversity. Conservation Biology, 13, 282-292.

Pirinen, P., Simola, H., Aalto, J., Kaukoranta, J., Karlsson, P., \& Ruuhela, R. (2012) Climatological statistics of Finland 1981-2010.

Post, E., Forchhammer, M.C., Bret-Harte, M.S., et al. (2009) Ecological dynamics across the Arctic associated with recent climate change. Science, 325, 1355-1358.

Reynard, E. (2009) Geomorphosites: definition and charasteristics. Geomorphosites (ed. by E. Reynard, P. Coratza, and G. Regolini-Bissig), pp. 51-63. Verlag Pfeil, Munich. 
le Roux, P.C. \& Luoto, M. (2014) Earth surface processes drive the richness, composition and occurrence of plant species in an arctic-alpine environment. Journal of Vegetation Science, 25, 45-54.

Ruxton, G.D. (2006) The unequal variance t-test is an underused alternative to Student's t-test and the Mann-Whitney U test. Behavioral Ecology, 688-690.

Secretariat of the Convention on Biologival Diversity (2014) Global Biodiversity Outlook 4.

Shannon, C.E. \& Weaver, W. (1949) The Mathematical Theory of Communication. University of Illinois Press, Urbana, IL.

Sharples, C. (1995) Geoconservation in forest management - pronciples and procedures. Tasforest, 7, 3750.

Simpson, E.H. (1949) Measurement of Diversity. Nature, 163, 688-688.

Socolar, J.B., Gilroy, J.J., Kunin, W.E., \& Edwards, D.P. (2016) How Should Beta-Diversity Inform Biodiversity Conservation ? Trends in Ecology \& Evolution, 31, 67-80.

Stein, A., Gerstner, K., \& Kreft, H. (2014) Environmental heterogeneity as a universal driver of species richness across taxa, biomes and spatial scales. Ecology Letters, 17, 866-880.

Tilk, M., Mandre, M., Jaan, K., \& Kõresaar, P. (2011) Ground vegetation under natural stress conditions in Scots pine forests on fixed sand dunes in southwest Estonia. Journal of Forest Research, 16, 223-227.

Torres, A., Brandt, J., Lear, K., \& Liu, J. (2017) A looming tragedy of the sand commons. Science (New York, N.Y.), 357, 970-971.

Tukiainen, H., Alahuhta, J., Field, R., Ala-Hulkko, T., Lampinen, R., \& Hjort, J. (2017) Spatial relationship between biodiversity and geodiversity across a gradient of land-use intensity in high-latitude landscapes. Landscape Ecology, 32, 1049-1063.

Tuomisto, H. (2010) A diversity of beta diversities: Straightening up a concept gone awry. Part 1. Defining beta diversity as a function of alpha and gamma diversity. Ecography, 33, 2-22.

Ujházy, K., Fanta, J., \& Prach, K. (2011) Two centuries of vegetation succession in an inland sand dune area, central Netherlands. Applied Vegetation Science, 14, 316-325.

Vilmi, A., Alahuhta, J., Hjort, J., Kärnä, O.-M., Leinonen, K., Rocha, M.P., Tolonen, K.E., Tolonen, K.T., \& Heino, J. (2017) Geography of global change and species richness in the North. Environmental Reviews, 25, 184-192.

Whittaker, R.J., Willis, K.J., \& Field, R. (2001) Scale and species richness : towards a general, theory of species diversity hierarchical. Diversity, 28, 453-470.

Williams, P., Gibbons, D., Margules, C., Rebelo, A., Humphries, C., \& Pressey, R. (1996) A Comparison of Richness Hotspots, Rarity Hotspots, and Complementary Areas for Conserving Diversity of British Birds. Conservation Biology, 10, 155-174.

WWF (2018) Living Planet Report - 2018: Aiming Higher. WWF, Gland, Switzerland. 


\section{Biosketch}

Helena Tukiainen is a physical geographer whose research focuses on biodiversity-geodiversity dynamics, with an emphasis on high-latitude ecosystems. The research team consists of researchers and experts with different backgrounds and interests in geography, ecology, geology and the Geopark -network. Author contributions: M.K, J.H and H.T. conceived the ideas; H.T, J.H. M.K., and J.A. collected and analyzed the data; H.T. led the writing with contributions from M.K.; all authors commented on and edited the text.

\section{Supporting Information}

Additional Supporting Information includes Appendix S1 (Total beta diversity and its replacement and richness components in each landform), Appendix S2 (The topographical characteristics of different landforms and their relationship between vascular plant diversity measures) and Appendix S3 (Vascular plant species frequencies in the studied data). 